J. Dairy Sci. 98:1005-1018

http://dx.doi.org/10.3168/jds.2014-8578

(C) American Dairy Science Association ${ }^{\circledR}, 2015$.

\title{
Rapeseed or linseed in dairy cow diets over 2 consecutive lactations: Effects on adipose fatty acid profile and carry-over effects on milk fat composition in subsequent early lactation
}

\author{
S. Lerch, ${ }^{*} \dagger \ddagger^{1,2}$ J. A. A. Pires, ${ }^{*} \dagger \ddagger$ C. Delavaud, ${ }^{*} \dagger \ddagger$ K. J. Shingfield, $\S^{3}$ D. Pomiès, ${ }^{\star} \dagger \ddagger \#$ B. Martin, ${ }^{*} \dagger \ddagger$ \\ Y. Chilliard, ${ }^{*} † \ddagger$ and A. Ferlay* \\ *INRA, UMR1213 Herbivores, F-63122 Saint-Genès-Champanelle, France \\ †Clermont Université, VetAgroSup, UMR1213 Herbivores, BP 10448, F-63000 Clermont-Ferrand, France \\ ¥Université de Lyon, VetAgroSup, UMR1213 Herbivores, F-69280 Marcy l'Etoile, France \\ §MTT Agrifood Research Finland, Animal Production Research, FI-31600 Jokioinen, Finland \\ \#INRA, UE1296 Monts d'Auvergne, F-63210 Orcival, France
}

\section{ABSTRACT}

During early lactation, milk fatty acid (FA) composition is influenced by diet, animal genetics, and the high availability of preformed FA from body-fat mobilization. Long-term prepartum dietary oilseed supplementation could, therefore, modify milk FA composition postpartum in the subsequent lactation through changes in adipose tissue (AT) FA profile. To test this hypothesis, measurements were made in 19 Holstein cows fed grassbased diets containing no additional lipid (control, CTL; $\mathrm{n}=4$ ) or supplemented with extruded linseeds (EL; n $=4)$, cold-pressed fat-rich rapeseed meal (FRM; $\mathrm{n}=$ 6 ), or whole unprocessed rapeseeds (WR; $\mathrm{n}=5$ ) over 2 consecutive lactations (yr 1 and 2) and 2 dry periods. Oilseed supplements were withdrawn from the diets 23 $\mathrm{d}$ before the calving of yr 3, following the end of the previous experimental periods in yr 1 to 2 . Thereafter, all cows received a total mixed ration composed of grass silage, grass hay, and concentrates (forage:concentrate ratio of 70:30 on a dry-matter basis). Cows previously fed EL and WR had a lower milk fat content $(6.32 \%$ for CTL and FRM vs. $5.46 \%$ for EL and WR) and yield $(1.90 \mathrm{~kg} / \mathrm{d}$ for CTL and FRM vs. $1.61 \mathrm{~kg} / \mathrm{d}$ for EL and WR) during the first week of lactation. Treatment effects on milk fat content and yield did not persist into lactation wk 3 and 7. Whatever the week, EL and WR increased concentration of FA in milk synthesized de novo (i.e., carbon number $\leq 15 ; 17.1 \mathrm{~g} / 100 \mathrm{~g}$ of FA for CTL and FRM vs. $22.2 \mathrm{~g} / 100 \mathrm{~g}$ of FA for EL and

Received July 7, 2014.

Accepted October 22, 2014.

${ }^{1}$ Corresponding author: sylvain.lerch@univ-lorraine.fr

${ }^{2}$ Current address: Université de Lorraine, UR Animal et Fonctionnalités des Produits Animaux, EA 3998, USC INRA 340, ENSAIA TSA 40602, F-54518 Vandoeuvre-lès-Nancy, France.

${ }^{3}$ Current address: Institute of Biological, Environmental and Rural Sciences, Aberystwyth University, Gogerddan, Aberystwyth, SY23 3EB, United Kingdom.
WR) and decreased concentration and secretion of preformed FA (i.e., carbon number $\geq 17 ; 56.1 \mathrm{~g} / 100 \mathrm{~g}$ of FA for CTL and FRM vs. $49.9 \mathrm{~g} / 100 \mathrm{~g}$ of FA for EL and WR). Alterations in milk FA composition may be explained by the lower availability of mobilized FA for uptake by the mammary gland, as indicated by the lower plasma nonesterified FA concentrations for EL and WR compared with CTL and FRM. Prepartum EL feeding increased AT and milk concentration of 18:3n-3 (0.96 vs. $0.79 \mathrm{~g} / 100 \mathrm{~g}$ of milk FA for EL and the other groups, respectively) and intermediates of ruminal 18:3n-3 biohydrogenation. In contrast, FRM increased AT and milk concentration of ruminal cis-9 18:1 biohydrogenation intermediates. However, EL and FRM supplements resulted in a similar profile of 18-carbon FA isomers in AT (yr 2) and milk (yr 3, 4-10 wk after removing oilseeds from the diet). In conclusion, results confirm that long-term feeding of oilseed supplements alter AT FA composition and may influence milk FA composition during periods of extensive body-fat mobilization such as early lactation.

Key words: dairy cow, oilseed supplementation, carryover effect, adipose-tissue mobilization, milk fatty acid

\section{INTRODUCTION}

The effects of dietary oilseed supplements on bovine milk FA composition have been examined extensively (Chilliard et al., 2007; Ferlay et al., 2013; Shingfield et al., 2013). Feeding oilseeds to lactating cows decreases milk fat 4- to 16-carbon SFA and increases 18:0, cis-9 18:1, trans FA, and cis-9,trans-11 CLA concentrations. Such changes in milk FA composition may potentially influence the incidence of several chronic human diseases (Shingfield et al., 2008; Givens, 2010). During early lactation, dairy cows experience negative energy balance and extensive body-fat mobilization. At the same time, milk fat concentration of $\mathrm{FA}$ synthesized de novo is lower, and the content of preformed FA is 
higher, compared with mid or late lactation (Palmquist et al., 1993). Thus, the profile of preformed 18:1, 18:2, and 18:3 isomers in milk fat during early lactation partially reflects the FA composition of adipose tissue (AT; Chilliard et al., 2000). Furthermore, FA composition of AT in dairy cows is known to be altered by duodenal infusion of rapeseed oil in periods of positive energy balance during mid lactation but not during early lactation when energy balance is negative and extensive body-fat mobilization is used to support milk production (Chilliard et al., 1991).

Investigations on the carry-over effects of lipid supplementation on milk fat composition in the subsequent lactation are limited to studies examining the role of oilseeds fed during 5 to 7 wk prepartum (Morel et al., 2008; Santschi et al., 2009; Leiber et al., 2011). Supplementing with processed linseeds resulted in marginal increases in 18:3n-3 concentration of colostrum 1 or $2 \mathrm{~d}$ postpartum (Santschi et al., 2009; Leiber et al., 2011), whereas sunflower seeds caused a minor increase of 18:2n-6 in milk during the first week of lactation (Morel et al., 2008). We hypothesize that the relatively short duration of oilseed supplementation prepartum in these studies was insufficient to change the FA profile of AT and that a longer exposure to oilseed supplements would induce larger effects on AT FA composition, and thereby influence milk FA composition early postpartum in the subsequent lactation. The objective of this study was to assess whether long-term oilseed supplementation would alter AT FA profile in lactating cows and cause residual carry-over effects on milk FA composition during the beginning of the subsequent lactation.

\section{MATERIALS AND METHODS}

\section{Animals and Diets}

All experimental procedures were conducted in accordance with the French guidelines for experimental animal use. Fifty-eight dairy Holstein cows were recruited to a long-term experiment (Figure 1) and fed a control diet or a similar diet supplemented with processed oilseeds over 2 consecutive lactations. Details of the experimental design have been reported elsewhere (Lerch et al., 2012a,b,c). On completion of the second lactation of the experiment, only 19 out of the 58 cows initially recruited to the study were available during the beginning of the subsequent lactation, which was mostly because of reproduction problems. Those cows had been on one of the following experimental treatments during yr 1 and 2: control (CTL, 4 cows), extruded linseeds (EL, 4 cows), cold-pressed fat-rich rapeseed meal (FRM, 6 cows), or unprocessed whole rapeseeds (WR, 5 cows). Oilseed supplements were withdrawn 3 wk before calving to investigate possible carry-over effects on milk FA composition early postpartum.

During yr 1 and 2 of the experiment, cows received grass-based diets containing no additional lipid or supplemented with oilseed by-products. The control concentrate comprised pelleted wheat and solventextracted rapeseed meal (CTL), which was partially substituted by EL [extruded blend of linseeds and wheat (70:30, wt/wt); INZO ${ }^{\circ}$, Argentan, France], FRM (by-product of rapeseed oil extraction by cold pressure; Dock Moulin SA, Marneffe, Belgium), or WR (INZO ${ }^{\circ}$ ). For EL, FRM, and WR, oilseed supplements provided a minimum of $2.5 \%$ and a maximum of $5.1 \%$ of oil in diet DM (mean values of $2.9,3.1$, and $3.3 \%$ for EL, FRM, and WR, respectively, over the $2 \mathrm{yr}$ of the supplementation period). By design, cows received experimental treatments until the end of yr 2 of the experiment $(26$ $\pm 9 \mathrm{~d}$ before calving in yr 3), which corresponded to $732 \pm 40 \mathrm{~d}$ (mean $\pm \mathrm{SD}$ ) of oilseed supplementation. Thereafter, experimental concentrates were progressively removed from the diet over a period of $3 \mathrm{~d}$. From $23 \pm 9 \mathrm{~d}$ (mean $\pm \mathrm{SD}$ ) before calving, all 19 cows received a similar control diet containing no oilseed

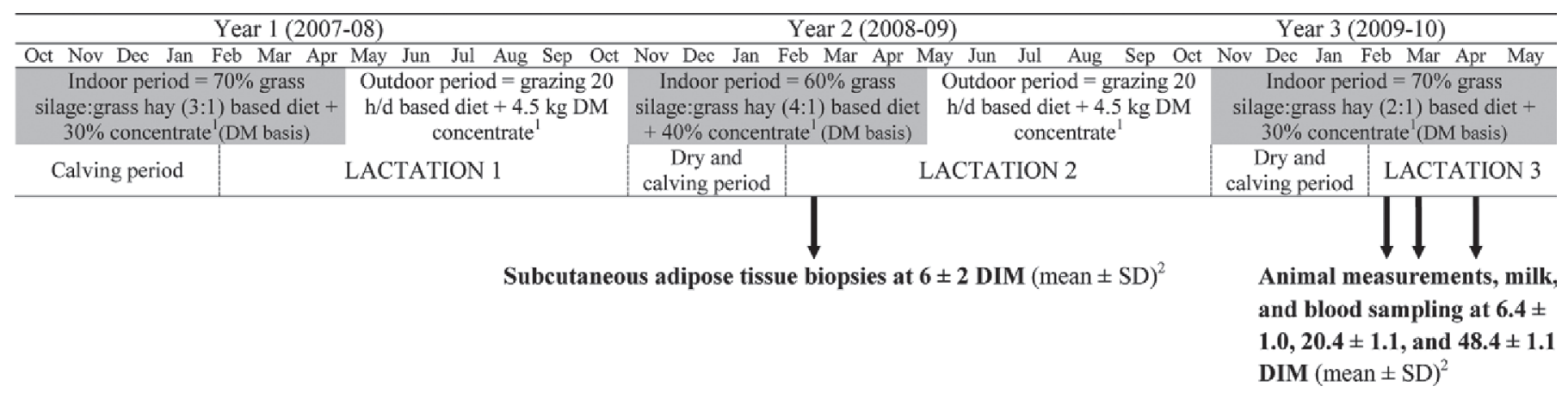

Figure 1. Summary of the experimental design used in study yr 1 to $3 .{ }^{1}$ From wk 6 of lactation in yr 1 , until $23 \pm 9 \mathrm{~d}$ (mean \pm SD) before calving in yr 3, concentrates contained no additional lipid (control) or oilseed supplements (extruded linseeds, cold-pressed fat-rich rapeseed meal, and whole unprocessed rapeseeds; Lerch et al., 2012a). Thereafter, all cows received the control concentrate until $49 \mathrm{~d}$ postpartum into the third lactation. ${ }^{2}$ Timing relative to measurement and sampling initiated at the onset of lactation in yr 2 and 3. 
Table 1. Chemical composition of forages and concentrate mixtures fed during pre- and postpartum periods

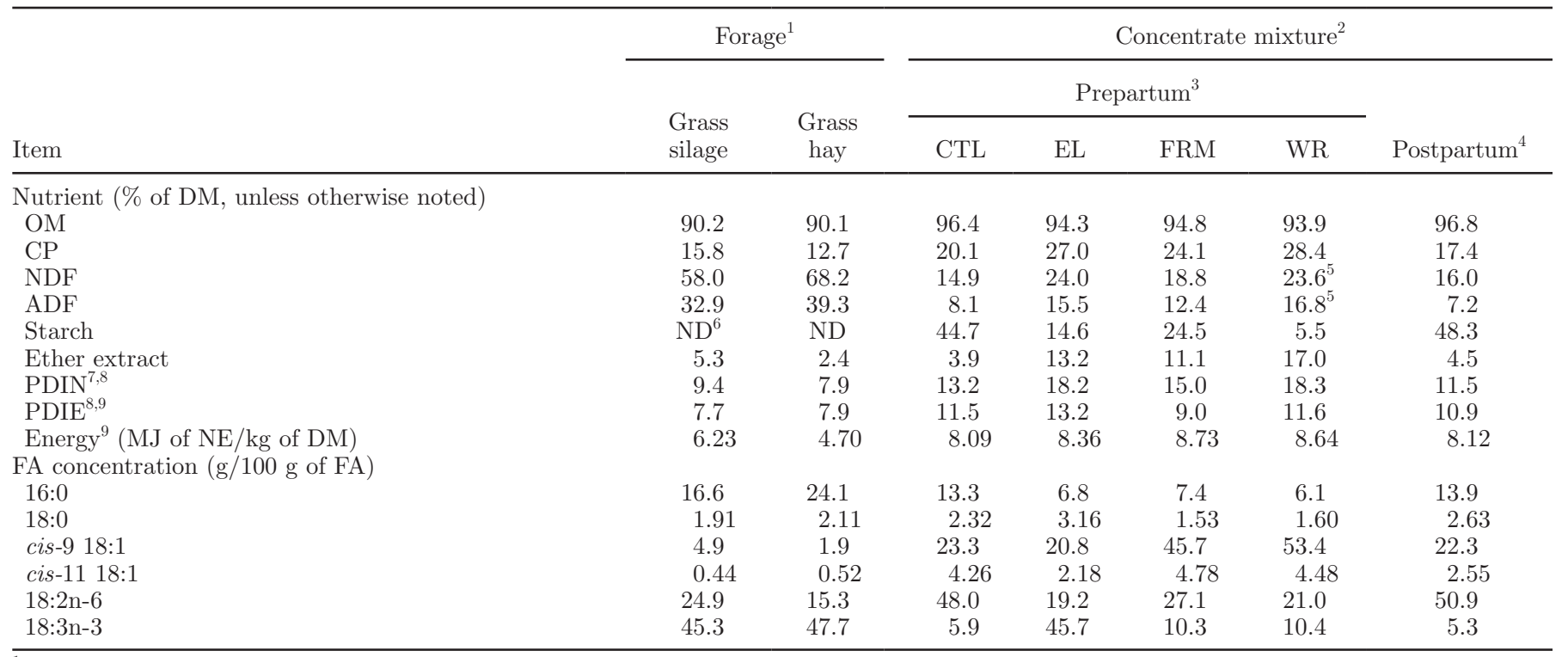

${ }^{1}$ Forage mixtures contained (\% DM) grass silage (75) and grass hay (25) prepartum and grass silage (68) and grass hay (32) postpartum.

${ }^{2}$ Cows received $4.5 \mathrm{~kg}$ of DM per day of concentrate prepartum and $30 \%$ of concentrate in diet DM postpartum.

${ }^{3}$ Before $-26 \pm 8.8 \mathrm{~d}($ mean $\pm \mathrm{SD})$ prepartum, concentrate mixtures contained $(\% \mathrm{DM})$ no oilseed supplement $[$ control, CTL, $\mathrm{n}=4$; pelleted wheat (73; 95 wheat +5 molasses) and solvent-extracted rapeseed meal (27)] or an estimated amount of $2.5 \%$ of oil in diet DM from extruded linseeds [EL, $\mathrm{n}=4$; pelleted wheat (9), solvent-extracted rapeseed meal (51), and EL (40; extruded blend of $70 \%$ linseeds and $30 \%$ wheat, weight basis)], cold-pressed fat-rich rapeseed meal [FRM, $\mathrm{n}=6$; pelleted wheat (40) and FRM (60)], or whole unprocessed rapeseeds [WR, $\mathrm{n}=5$; pelleted wheat (9), solvent-extracted rapeseed meal (60), and WR (31)]. After $-23 \pm 8.8 \mathrm{~d}$ (mean \pm SD) prepartum, all cows ( $\mathrm{n}=19)$ received the CTL concentrate mixture containing no oilseed supplement.

${ }^{4}$ Postpartum, all cows $(n=19)$ received the same concentrate mixture without oilseed supplement $(83 \%$ of pelleted wheat and $17 \%$ of solventextracted rapeseed meal, DM basis).

${ }^{5}$ Estimated, based on published values (INRA, 2007).

${ }^{6} \mathrm{ND}=$ not determined.

${ }^{7}$ True protein digestible in the small intestine when protein supply is limited (INRA, 2007).

${ }^{8}$ Determined from chemical analyses using the INRAtion and Prev'Alim Software (INRA, 2006).

${ }^{9}$ True protein digestible in the small intestine when energy supply is limited (INRA, 2007).

supplements, until the end of the experiment (wk 7 postpartum).

Before calving in yr 3 , cows were dried off for $61 \pm 17$ $\mathrm{d}($ mean $\pm \mathrm{SD})$ and received a grass silage- and grass hay-based diet and $4.5 \mathrm{~kg}$ of concentrate DM per day. Concentrates were fed twice daily in equal amounts separately from forages. After calving, cows received a TMR (70:30 forage-to-concentrate ratio) composed of (on a \% DM basis) grass silage (46.5), grass hay (22), pelleted wheat (25), solvent-extracted rapeseed meal (5), and a mineral and vitamin premix (1.5) offered at $1000 \mathrm{~h}$ to ensure $10 \%$ refusals. The same sources of grass hay, grass silage, and concentrates were used for the pre- and postpartum diets. Composition of forages and concentrate mixtures fed before and after calving in yr 3 are presented in Table 1. Cows were housed in a freestall barn with individual feed bunks equipped with automatic gates, milked at 0630 and $1600 \mathrm{~h}$, and had free access to fresh water. Feed refusals were weighed on $4 \mathrm{~d}$ per week.

\section{Sampling, Measurements, and Chemical Analysis}

Feed and Feedstuffs. Subsamples of feed and refusals were collected weekly and composited monthly for the determination of DM. Samples of oilseed supplements (EL, FRM, and WR) fed during the dry period for chemical analyses were collected on September 1, 2009. Subsamples of other feedstuffs were collected 5 times during the dry period and subsequent lactation, composited by feed type, and analyzed for ash, CP, NDF, ADF, starch, ether extract, and FA composition (Lerch et al., 2012a,b). Chemical composition and nutritional value of forages and concentrates are presented in Table 1.

Animal Measures and Sampling. Individual BW and BCS were recorded during wk 1, 3, and 7 of lactation $[7.9 \pm 0.7,21.9 \pm 0.7$, and $49.3 \pm 3.3$ DIM (mean $\pm \mathrm{SD}$ ), respectively]. Daily milk yield was recorded individually, and milk samples $(30 \mathrm{~mL})$ were collected over 4 consecutive milkings at wk 1, 3, and 7 of lacta- 
tion $[9.3 \pm 1.9,23.3 \pm 1.9$, and $51.2 \pm 1.9$ DIM (mean $\pm \mathrm{SD}$ ), respectively] and analyzed for fat, protein, and lactose content and SCC (Lerch et al., 2012a). Additional samples of milk were collected without preservative over 2 consecutive milkings during wk 1,3 , and 7 of lactation $[6.4 \pm 1.0,20.4 \pm 1.1$, and $48.4 \pm 1.1$ DIM (mean $\pm \mathrm{SD}$ ), respectively], stored at $-20^{\circ} \mathrm{C}$, and analyzed for FA composition (Lerch et al., 2012b).

Blood sampling was performed at $0900 \mathrm{~h}$, after morning milking and before feeding on the same dates as for milk FA analyses $[6.4 \pm 1.0,20.4 \pm 1.1$, and $48.4 \pm$ 1.1 DIM (mean $\pm \mathrm{SD}$ )]. Blood samples were collected from coccygeal vessels into tubes containing EDTA (2.1 $\mathrm{mg} / \mathrm{mL}$ ), and plasma was separated and frozen until analyses (Lerch et al., 2012a). Intra- and interassay CV were 6.4 and $6.6 \%$ for NEFA, 2.5 and $2.7 \%$ for BHBA, and 0.9 and $1.5 \%$ for glucose, respectively.

Adipose Tissue Biopsies. On $6 \pm 2$ DIM (mean $\pm \mathrm{SD}$ ) in study yr 2 , corresponding to $355 \pm 2 \mathrm{~d}$ on experimental treatments, samples of subcutaneous AT were collected for FA composition analysis. Skin was incised $(4 \mathrm{~cm})$ with a scalpel under local subcutaneous anesthesia $(5 \mathrm{~mL}$ of $2 \%$ lidocaine; Aguettant, Lyon, France). All AT was collected from the left side of the thorax, immediately behind to the point of the elbow. Approximately $50 \mathrm{mg}$ of AT harvested was rinsed with $0.9 \%$ sterile saline solution $(\mathrm{wt} / \mathrm{vol})$ at $37^{\circ} \mathrm{C}$, inspected to verify tissue homogeneity, and snap frozen in liquid nitrogen. Samples were stored at $-80^{\circ} \mathrm{C}$ before FA analysis. Following the biopsy, incisions were sutured and treated with a general antiseptic (chlorhexidine, Cicajet 18; Virbac France, Carros, France).

Lipid Analyses. Lipids were extracted from AT samples according to Folch et al. (1957). Briefly, $50 \mathrm{mg}$ of AT was weighted in glass tubes and homogenized in $9 \mathrm{~mL}$ of a mixture of chloroform and methanol (2:1, $\mathrm{vol} / \mathrm{vol}$ ). Once homogenization was complete, $18 \mathrm{~mL}$ of $\mathrm{NaCl}$ 0.75\% (wt/vol) was added, and tubes were vigorously agitated and centrifuged at $10^{\circ} \mathrm{C}$ and $1,100 \times g$ during $10 \mathrm{~min}$. A total of $3 \mathrm{~mL}$ of the lower phase was collected, and the upper phase was reextracted with 3 $\mathrm{mL}$ of a mixture of chloroform, methanol, and $0.58 \%$ (wt/vol) of $\mathrm{NaCl}$ (86:14:1, vol/vol). Lower phases were combined, dried under nitrogen, and resuspended in $500 \mu \mathrm{L}$ of chloroform. Neutral and polar lipids in organic extracts were separated by solid-phase extraction using Sep-pack Vac RC (500 mg)-NH2 columns (WAT 054515; Waters, Saint-Quentin, France) according to Juaneda and Rocquelin (1985). In brief, $500 \mu \mathrm{L}$ of extracted lipid was loaded at the top of the cartridge, and neutral lipids were eluted with $20 \mathrm{~mL}$ of chloroform. The neutral lipids fraction recovered was dried under nitrogen, resuspended in $100 \mu \mathrm{L}$ of toluene, and converted into FAME, using methanol, boron trifluoride
(95:5, vol/vol) as catalyst according to Glass (1971). The total profile of neutral lipid FAME in a 1- $\mu \mathrm{L}$ sample at a split ratio of 1:50 was determined by GC using a Trace-GC 2000 Series gas chromatograph equipped with a flame ionization detector (Thermo Finnigan, Les Ulis, France) and a 100-m fused silica capillary column (i.d. of $0.25 \mathrm{~mm}$ ) coated with a $0.2-\mu \mathrm{m}$ film of cyanopropyl polysiloxane (CP-Sil 88; Chrompack Nederland BV, Middelburg, the Netherlands). The injector temperature was maintained at $250^{\circ} \mathrm{C}$ and the detector temperature at $255^{\circ} \mathrm{C}$. Hydrogen was used as the carrier and fuel gas. The injector pressure was held constant at $158.6 \mathrm{kPa}$. The FAME were separated using an oven gradient program (Loor et al., 2004). Isomers of 18:1 were further resolved in a separate analysis under isothermal conditions $\left(170^{\circ} \mathrm{C}\right.$; Shingfield et al., 2003). Two samples of AT were found to contain very small amounts of lipid and were therefore excluded from statistical analysis (one sample for both FRM and WR).

The FAME for samples of ground, lyophilized feeds were prepared using a one-step extraction and methylation procedure (Sukhija and Palmquist, 1988). The profile of total FAME in feed ingredients was determined by GC as used for AT.

Lyophilized milk samples from morning and evening milking were pooled (60 and $40 \mathrm{mg}$ of morning and evening samples, respectively) to provide a daily composite sample for each cow. The FAME in 100-mg samples of lyophilized milk were prepared using a one-step extraction and methylation procedure, and the entire profile of FAME in a $0.6-\mu \mathrm{L}$ sample at a split ratio of 1:50 was determined by GC as previously described for FAME analysis of AT (Lerch et al., 2012b).

Independent of sample matrix (feedstuff, AT, or milk), chromatographic peaks were routinely identified by retention-time comparisons with commercial authentic standards containing mixtures of FAME (Lerch et al., 2012b). Correction factors to account for the carbon deficiency in the flame-ionization detector response were estimated as described elsewhere (Lerch et al., 2012b). Methyl esters in milk fat not available as authentic standards were identified by retention time and elution order comparisons with samples collected during yr 1 and 2 for which electron impact ionization spectra of FAME and 4,4-dimethyloxazoline derivatives were obtained by GC-MS analysis (Lerch et al., $2012 b, c)$.

\section{Calculations and Statistical Analysis}

Milk secretion of individual FA was calculated according to Glasser et al. (2007). Statistical analyses were performed using the MIXED procedure of SAS (2003). For AT FA composition, data were analyzed by 
a model that included the fixed effects of dietary treatment (CTL, EL, FRM, or WR) and parity and random effect of cow. For all other measurements collected in yr 3 , data were analyzed by a model for repeated measures that included group (corresponding to CTL, EL, FRM, or WR treatment applied during yr 1 and 2), lactation week $(1,3$, or 7$)$, and interactions of group by lactation week as fixed effects and cow as a random effect, using a spatial power covariance structure. Denominator degrees of freedom were calculated using the Kenward-Rogers adjustment. When interactions of group by lactation week were significant, the SLICE option was used to compare group differences at each sampling time. Logarithmic transformation (base 10) of experimental data was performed when required to comply with the assumptions of normality and homoscedasticity of residuals. When transformation was necessary (milk SCC, plasma NEFA, and BHBA concentrations), least squares means and standard error of the mean were calculated from untransformed values, whereas declared $P$-values reflect statistical analysis of transformed data. Treatment or group, and lactation week differences were determined based on $t$-tests and declared significant at $P \leq 0.05$. Trends toward significance were considered at $0.05<P \leq 0.10$. Values reported are least squares means and standard error of the mean.

\section{RESULTS}

\section{Intake, Milk Production, and Plasma Metabolites}

Lactation week and carry-over effects of oilseed supplements on intake, milk yield and composition, BW, BCS, energy and true protein truly digestible in the small intestine balances, and plasma metabolite concentrations during yr 3 are presented in Table 2 . Temporal changes in these parameters are described in Figures 2A, 2B, and 2C.

Compared with the CTL group, milk fat content tended $(P=0.06)$ to be lower for EL and WR (Figure $2 \mathrm{~A})$ and milk fat yield tended $(P=0.09)$ to be lower for WR than for the CTL group during the first week of lactation $(P<0.03$ for lactation week $\times$ group interaction). Treatment effects on milk fat and yield did not persist $(P>0.10)$ into lactation wk 3 and 7 . Milk protein content was higher $(P<0.001)$ for EL compared with other groups and lower $(P<0.001)$ for FRM than WR. Milk protein yield was lower $(P<0.01)$ for FRM than for CTL and for rapeseed groups (FRM and WR) than for EL. Compared with CTL and EL, BW was lower $(P<0.01)$ for rapeseed groups (FRM and WR). Relative to the CTL, decreases in BW from lactation wk 1 to 7 tended $(P=0.10)$ to be lower for rapeseed groups. Plasma NEFA concentration was lower $(P=$ 0.02 ) for EL than for CTL and FRM and similarly lower for WR than the CTL (Table 2 and Figure 2C). Irrespective of treatment, plasma NEFA concentrations tended $(P=0.10)$ to decrease during early lactation. Treatments had no effect $(P>0.10)$ on plasma BHBA and glucose concentrations, whereas BHBA concentrations were higher $(P<0.01)$ in lactation wk 3 than wk 1 or 7 (Table 2 ).

\section{Adipose Tissue FA Composition}

Concentrations of FA in AT are presented in Table 3. Overall, treatments had relatively few effects on individual SFA, odd- and branched-chain, and cis FA concentrations in subcutaneous AT (Table 3). Compared with the CTL, WR increased $(P \leq 0.05)$ 18:0 and 20:4n- 6 concentrations. Treatment EL increased $(P$ $<0.01)$ 18:3n-3 concentration, whereas rapeseed treatments (FRM and WR) increased $(P<0.01)$ 20:0, but only WR increased $(P<0.01)$ cis-9 20:1 abundance. Furthermore, both EL and FRM increased $(P=0.03)$ cis-12 18:1 concentration compared with CTL and WR (Table 3).

Relative to CTL, WR had no effect $(P>0.10)$ on individual trans $\mathrm{FA}$ concentrations in $\mathrm{AT}$, except for a marginal increase $(P=0.02 ;+0.04 \mathrm{~g} / 100 \mathrm{~g}$ of FA $)$ in cis-9,trans-11,cis-15 conjugated linolenic acid (CLnA) concentration. Compared with the CTL, both EL and FRM increased $(P \leq 0.02)$ total trans $\mathrm{FA}$, trans-9 18:1, trans-16 18:1, and cis-9,trans-11 CLA concentrations. Moreover, EL increased $(P<0.01)$ trans-11,cis-15 18:2 and $\Delta 9,11,15$ CLnA abundances, whereas FRM increased $(P \leq 0.04)$ trans-6, $-7,-8,-10$, and -11 18:1 concentrations (Table 3 ).

\section{Milk FA Composition}

Lactation week and carry-over effects of long-term prepartum oilseed supplementations on the concentration and secretion of major FA (with an average concentration $\geq 0.15 \mathrm{~g} / 100 \mathrm{~g}$ of FA) in milk during yr 3 are presented in Table 4 and in Figures 2D to 2G. Effects on milk minor FA concentrations (on average, FA with concentrations $<0.15 \mathrm{~g} / 100 \mathrm{~g}$ of FA) are presented in Figure 2H and in Supplemental Table S1 (http:// dx.doi.org/10.3168/jds.2014-8578).

Effects of Lactation Week. Milk concentrations of 13 - to 16 -carbon SFA increased $(P \leq 0.03)$ from lactation wk 1 to 7 , except for 16:0, whereas milk concentrations of 22:0, 23:0, and 24:0 increased $(P<0.01)$ from lactation wk 1 to 3 . Conversely, concentrations of 17:0 (Table 4), 18:0, (Table 4 and Figure 2D), and 18:0 iso (Supplemental Table S1; http://dx.doi.org/10.3168/ 
Table 2. Effects of dietary oilseed supplements fed over 2 consecutive lactations (105 $\pm 6 \mathrm{wk}$, mean \pm SD) on intake, milk yield and composition, BW, BCS, energy and protein balances, and plasma metabolite concentrations of cows during early lactation (yr 3) fed a diet containing no oilseeds from $21 \mathrm{~d}$ prepartum to $49 \mathrm{~d}$ postpartum

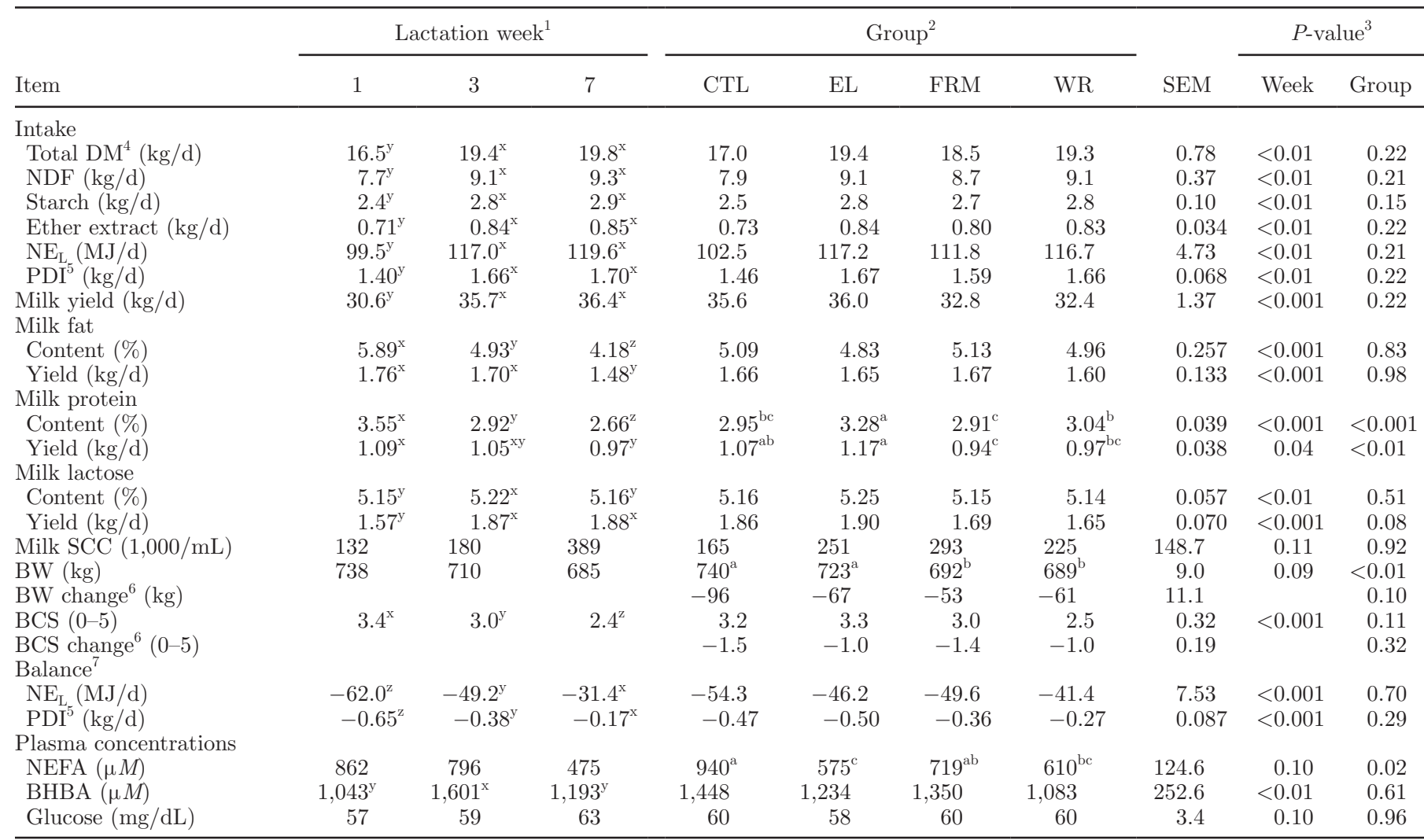

${ }^{\mathrm{x}-\mathrm{z}}$ Within a row and between lactation week, means with different superscripts differ at $P<0.05$.

${ }^{\mathrm{a}-\mathrm{c}}$ Within a row and between groups, means with different superscripts differ at $P<0.05$.

${ }^{1}$ Measured at $9.3 \pm 1.9,23.3 \pm 1.9$, and $51.2 \pm 1.9$ DIM (mean \pm SD) for lactation wk 1, 3, and 7, respectively, except for BW and BCS: $7.9 \pm$ $0.7,21.9 \pm 0.7$, and $49.3 \pm 3.3$ DIM for lactation wk 1,3 , and 7 , respectively, and for plasma metabolite concentrations: $6.4 \pm 1.0,20.4 \pm 1.1$, and $48.4 \pm 1.1$ DIM for lactation wk 1,3 , and 7 , respectively.

${ }^{2}$ All cows $(n=19)$ received a diet based on grass silage and grass hay (forage:concentrate ratio of 70:30, DM basis) containing no oilseed supplement, after having received grass-based diets containing no oilseed supplement (control, CTL, $\mathrm{n}=4$ ) or 2.5 to $5.1 \%$ of oil in diet DM from extruded linseeds $(\mathrm{EL}, \mathrm{n}=4)$, cold-pressed fat-rich rapeseed meal (FRM, $\mathrm{n}=6)$, or whole unprocessed rapeseeds $($ WR, $\mathrm{n}=5)$ over 2 consecutive lactations.

${ }^{3}$ Interaction of week by group was not significant $(P>0.10)$, except for milk fat content $(P<0.01)$ and yield $(P=0.03)$.

${ }^{4}$ Total mixed ration composed of (\% DM basis) grass silage (46.5), grass hay (22.0), pelleted wheat (25.0), solvent-extracted rapeseed meal (5.0), and a mineral and vitamin premix (1.5).

${ }^{5}$ True protein truly digestible in the small intestine (INRA, 2007).

${ }^{6}$ Changes in BW and BCS between $7.9 \pm 0.7$ (lactation wk 1) and $49.3 \pm 3.3$ (lactation wk 7) DIM (lactation wk 7 minus lactation wk 1 ).

${ }^{7}$ Balance $=$ intake minus requirements for maintenance and production, calculated according to INRA (2007).

jds.2014-8578) decreased $(P<0.001)$ from lactation wk 1 to 3. Milk concentrations of cis-9 MUFA containing 10 - to 20 -carbons increased $(P<0.01)$ from lactation wk 1 to 3 but remained constant or increased $(P<$ 0.01 ) by wk 7 (Table 4 and Supplemental Table S1; http://dx.doi.org/10.3168/jds.2014-8578), except cis-9 17:1 and cis-9 18:1 (Table 4 and Figure 2E; $P \geq 0.38$ ). Among n-3 PUFA, milk 20:4n-3 concentration increased $(P<0.05)$, whereas 18:3n-3, unresolved $22: 5 n-3$ and 26:0, 22:6n-3, unresolved 20:3n-3 and cis-13 22:1, and 20:5n-3 concentrations decreased $(P<0.05)$ from lacta- tion wk 1 to 3 , and remaining constant or decreased ( $P$ $<0.05$ ) by wk 7 (Table 4, Figure 2G, and Supplemental Table S1; http://dx.doi.org/10.3168/jds.2014-8578). Secretions of 16-carbon FA and FA with carbon number $\geq 17$ in milk were lower $(P \leq 0.05)$ during lactation wk 7 than wk 1 and 3 (Table 4 ).

Milk concentrations of trans-11, -12, and -14 16:1; cis-11, -15, and -16 18:1; trans-4, -5, -6, -7, -8, -10, -11, $-12,-13,-14$, and $-1618: 1$; and cis- 12, cis- 15 18:2, trans9,cis-12 18:2, trans-11,cis-15 18:2, trans-12,cis-15 18:2, and trans-11,trans-15 18:2 decreased $(P \leq 0.05)$ from 

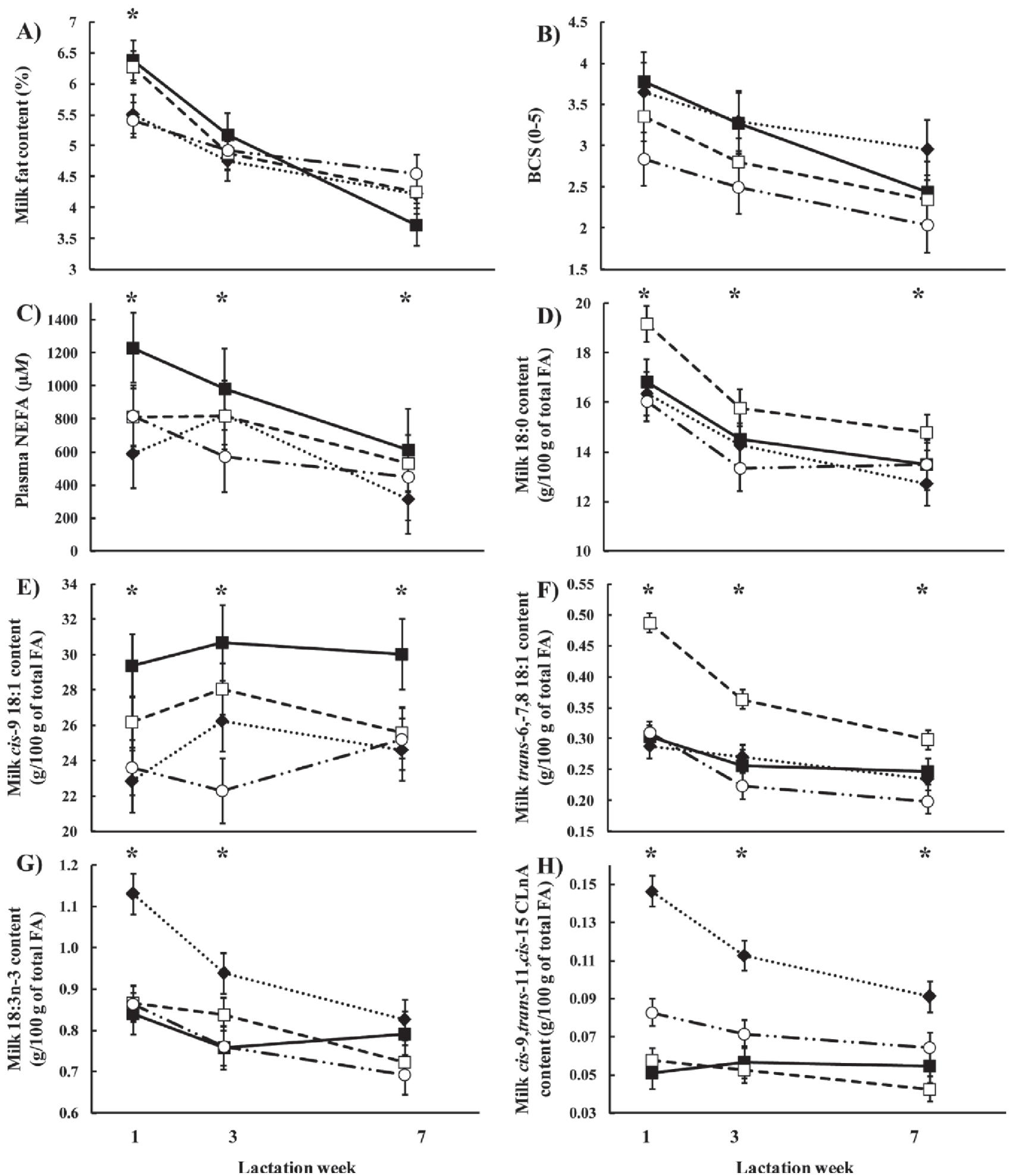

Figure 2. (A) Milk fat content, (B) BCS, (C) plasma NEFA concentration, and concentrations of (D) 18:0, (E) cis-9 18:1, (F) trans-6, -7, -8 18:1, (G) 18:3n-3, and (H) cis-9,trans-11,cis-15 conjugated linolenic acid (CLnA) in milk fat early postpartum in cows (yr 3) fed a grass silage and grass hay-based diet (forage:concentrate ratio of 70:30, DM basis) containing no oilseed supplement after receiving grass-based diets containing no oilseed supplement (control diet, - - - $\mathrm{n}=4$ ) or 2.5 to $5.1 \%$ of oil in diet DM from extruded linseeds $(\cdots \cdots \cdots$ cold-pressed fat-rich rapeseed meal $(--\square--; \mathrm{n}=6)$, or whole unprocessed rapeseeds $(-\cdots \bigcirc \cdots-; \mathrm{n}=5)$ over 2 consecutive years (lactations). Each point represents group least squares means, and error bars indicate standard error of the mean. $P$-values are reported in Tables 2 and 4 and Supplemental Table S1 (http://dx.doi.org/10.3168/jds.2014-8578). An asterisk indicates a significant group effect in the designated week of lactation. 
Table 3. Effects of oilseed supplements fed over $1 \mathrm{yr}(51 \pm 0.3 \mathrm{wk}$, mean $\pm \mathrm{SD}$ ) on the concentrations of FA in subcutaneous adipose tissue of early-lactating cows (5.8 $\pm 2.3 \mathrm{DIM}$, mean $\pm \mathrm{SD}$ ) during lactation preceding the $21 \mathrm{~d}$ prepartum and $49 \mathrm{~d}$ postpartum experimental test period in the present experiment ${ }^{1,2}$

\begin{tabular}{|c|c|c|c|c|c|c|}
\hline FA concentration $(\mathrm{g} / 100 \mathrm{~g}$ of $\mathrm{FA})$ & CTL & EL & FRM & WR & SEM & $P$-value, treatment \\
\hline 12:0 & 0.02 & 0.04 & 0.04 & 0.05 & 0.010 & 0.42 \\
\hline $14: 0$ & 2.19 & 2.55 & 2.37 & 1.82 & 0.209 & 0.10 \\
\hline $14: 0$ iso & 0.02 & 0.03 & 0.03 & 0.04 & 0.008 & 0.40 \\
\hline cis-9 14:1 & 0.91 & 0.93 & 0.78 & 0.77 & 0.157 & 0.82 \\
\hline $15: 0$ & 0.22 & 0.25 & 0.28 & 0.27 & 0.021 & 0.16 \\
\hline 15:0 anteiso & 0.10 & 0.11 & 0.14 & 0.14 & 0.014 & 0.18 \\
\hline 15:0 iso & 0.10 & 0.11 & 0.11 & 0.11 & 0.016 & 0.95 \\
\hline $16: 0$ & 27.2 & 25.3 & 25.9 & 24.1 & 0.79 & 0.08 \\
\hline 16:0 iso & 0.08 & 0.11 & 0.11 & 0.12 & 0.014 & 0.33 \\
\hline cis-7 $16: 1^{3}$ & 0.09 & 0.10 & 0.10 & 0.13 & 0.019 & 0.48 \\
\hline cis-9 16:1 + 17:0 anteiso & 5.31 & 5.94 & 4.62 & 4.53 & 0.475 & 0.14 \\
\hline cis-11 16:1 & 0.21 & 0.20 & 0.13 & 0.17 & 0.020 & 0.07 \\
\hline trans-9 16:1 + 17:0 iso & 0.29 & 0.29 & 0.36 & 0.34 & 0.050 & 0.69 \\
\hline $17: 0$ & 0.62 & 0.56 & 0.57 & 0.65 & 0.061 & 0.61 \\
\hline cis-8 17:1 & 0.04 & 0.04 & 0.04 & 0.05 & 0.006 & 0.47 \\
\hline cis-9 17:1 & 0.52 & 0.50 & 0.39 & 0.48 & 0.046 & 0.24 \\
\hline $18: 0$ & $12.4^{\mathrm{bc}}$ & $11.2^{\mathrm{c}}$ & $15.8^{\mathrm{ab}}$ & $16.7^{\mathrm{a}}$ & 1.52 & 0.05 \\
\hline 18:0 iso & 0.09 & 0.09 & 0.09 & 0.12 & 0.011 & 0.09 \\
\hline 11-cyclohexyl-11:0 & 0.11 & 0.06 & 0.22 & 0.20 & 0.107 & 0.57 \\
\hline cis-9 $18: 1^{4}$ & 40.8 & 40.4 & 36.9 & 37.4 & 1.93 & 0.36 \\
\hline cis-11 18:1 & 1.79 & 1.66 & 1.35 & 1.73 & 0.164 & 0.23 \\
\hline cis-12 18:1 & $0.12^{\mathrm{b}}$ & $0.17^{\mathrm{a}}$ & $0.15^{\mathrm{a}}$ & $0.12^{\mathrm{b}}$ & 0.012 & 0.03 \\
\hline cis-13 18:1 & 0.49 & 0.39 & 0.33 & 0.35 & 0.050 & 0.19 \\
\hline cis-16 18:1 + cis-9,trans-14 18:2 $2^{5}$ & $0.09^{\mathrm{b}}$ & $0.25^{\mathrm{a}}$ & $0.23^{\mathrm{a}}$ & $0.12^{\mathrm{b}}$ & 0.021 & $<0.001$ \\
\hline trans-6,-7,-8 18:1 & $0.08^{\mathrm{b}}$ & $0.13^{\mathrm{b}}$ & $0.40^{\mathrm{a}}$ & $0.11^{\mathrm{b}}$ & 0.037 & $<0.001$ \\
\hline trans-9 18:1 & $0.16^{\mathrm{c}}$ & $0.22^{\mathrm{b}}$ & $0.45^{\mathrm{a}}$ & $0.17^{\mathrm{c}}$ & 0.020 & $<0.001$ \\
\hline trans-10 18:1 & $0.16^{\mathrm{b}}$ & $0.17^{\mathrm{b}}$ & $0.47^{\mathrm{a}}$ & $0.14^{\mathrm{b}}$ & 0.049 & $<0.001$ \\
\hline trans-11 18:1 & $0.76^{\mathrm{bc}}$ & $1.01^{\mathrm{ab}}$ & $1.18^{\mathrm{a}}$ & $0.65^{\mathrm{c}}$ & 0.134 & 0.04 \\
\hline trans-16 $18: 1^{6}$ & $0.12^{\mathrm{b}}$ & $0.23^{\mathrm{a}}$ & $0.23^{\mathrm{a}}$ & $0.13^{\mathrm{b}}$ & 0.021 & $<0.01$ \\
\hline $18: 2 \mathrm{n}-6$ & 0.85 & 0.94 & 0.97 & 1.09 & 0.118 & 0.55 \\
\hline cis-9,trans-13 18:2 & 0.14 & 0.40 & 0.33 & 0.32 & 0.065 & 0.11 \\
\hline trans- 11, cis- $15 \quad 18: 2$ & $0.08^{\mathrm{b}}$ & $0.21^{\mathrm{a}}$ & $0.10^{\mathrm{b}}$ & $0.09^{\mathrm{b}}$ & 0.023 & $<0.01$ \\
\hline cis-9,trans-11 CLA $^{7}$ & $0.42^{\mathrm{b}}$ & $0.57^{\mathrm{a}}$ & $0.58^{\mathrm{a}}$ & $0.34^{\mathrm{b}}$ & 0.059 & 0.02 \\
\hline $18: 3 n-3^{8}$ & $0.52^{\mathrm{b}}$ & $0.76^{\mathrm{a}}$ & $0.54^{\mathrm{b}}$ & $0.61^{\mathrm{b}}$ & 0.041 & $<0.01$ \\
\hline cis-9,trans-11,cis-15 CLnA ${ }^{9}$ & $0.02^{\mathrm{c}}$ & $0.12^{\mathrm{a}}$ & $0.03^{\mathrm{c}}$ & $0.06^{\mathrm{b}}$ & 0.008 & $<0.001$ \\
\hline cis-9,trans-11,trans-15 CLnA $^{9}$ & $0.02^{\mathrm{b}}$ & $0.04^{\mathrm{a}}$ & $0.02^{\mathrm{b}}$ & $0.03^{\mathrm{b}}$ & 0.006 & $<0.01$ \\
\hline $20: 0$ & $0.12^{\mathrm{b}}$ & $0.12^{\mathrm{b}}$ & $0.26^{\mathrm{a}}$ & $0.32^{\mathrm{a}}$ & 0.042 & $<0.01$ \\
\hline cis-9 20:1 & $0.07^{\mathrm{b}}$ & $0.07^{\mathrm{b}}$ & $0.09^{\mathrm{b}}$ & $0.13^{\mathrm{a}}$ & 0.011 & $<0.01$ \\
\hline $20: 3 n-3$ & 0.09 & 0.04 & 0.11 & 0.18 & 0.055 & 0.33 \\
\hline $20: 3 n-6$ & 0.03 & 0.03 & 0.03 & 0.05 & 0.007 & 0.26 \\
\hline $20: 4 n-3$ & 0.02 & 0.04 & 0.02 & 0.04 & 0.010 & 0.27 \\
\hline $20: 4 n-6$ & $0.04^{\mathrm{b}}$ & $0.03^{\mathrm{b}}$ & $0.03^{\mathrm{b}}$ & $0.08^{\mathrm{a}}$ & 0.011 & $<0.01$ \\
\hline $20: 5 n-3$ & 0.02 & 0.03 & 0.02 & 0.04 & 0.006 & 0.17 \\
\hline $22: 0$ & 0.02 & 0.02 & 0.03 & 0.05 & 0.012 & 0.20 \\
\hline $22: 5 n-3$ & 0.06 & 0.12 & 0.08 & 0.12 & 0.019 & 0.14 \\
\hline 23:0 & 0.02 & 0.03 & 0.03 & 0.03 & 0.007 & 0.47 \\
\hline \multicolumn{7}{|l|}{ Summary } \\
\hline$\Sigma$ SFA & 43.4 & 40.2 & 46.0 & 44.5 & 1.38 & 0.07 \\
\hline$\Sigma$ Odd- and branched-chain FA & 1.9 & 1.9 & 2.0 & 2.0 & 0.11 & 0.74 \\
\hline$\Sigma$ MUFA & 51.9 & 52.2 & 47.9 & 46.0 & 2.53 & 0.24 \\
\hline$\Sigma$ Trans $\mathrm{FA}$ & $2.1^{\mathrm{b}}$ & $3.2^{\mathrm{a}}$ & $4.0^{\mathrm{a}}$ & $2.1^{\mathrm{b}}$ & 0.34 & $<0.01$ \\
\hline$\Sigma$ PUFA & 2.4 & 3.4 & 2.9 & 3.2 & 0.23 & 0.08 \\
\hline$\Sigma \mathrm{n}-3 \mathrm{FA}$ & 0.76 & 0.98 & 0.82 & 1.00 & 0.118 & 0.10 \\
\hline$\Sigma \mathrm{n}-6 \mathrm{FA}$ & 0.93 & 1.00 & 0.98 & 1.24 & 0.125 & 0.28 \\
\hline
\end{tabular}

${ }^{a-c}$ Within a row, means with different superscript letters differ at $P<0.05$.

${ }^{1}$ Concomitant to oilseed supplementation (yr 2 of the long-term experiment; Lerch et al, 2012a).

${ }^{2}$ Cows received grass silage and hay-based diets with $4.4 \mathrm{~kg}$ of DM/d of concentrate containing no oilseed supplement (control, CTL; $\mathrm{n}=4$ ) or 2.5 to $3.0 \%$ of oil in diet DM from extruded linseeds (EL; $\mathrm{n}=4$ ), coldpressed fat-rich rapeseed meal $(\mathrm{FRM} ; \mathrm{n}=5)$, or whole unprocessed rapeseeds $(\mathrm{WR} ; \mathrm{n}=4)$.

${ }^{3}$ Contains cis-8 $16: 1$ as a minor component.

${ }^{4}$ Contains cis-10 18:1 and trans-13, -14, -15 18:1 as minor components.

${ }^{5}$ Coelutes with cis-9,trans-12 18:2.

${ }^{6}$ Contains cis-14 18:1 as a minor component.

${ }^{7}$ Contains trans-7,cis-9 CLA and trans-8,cis-10 CLA as minor components.

${ }^{8}$ Contains cis-11 20:1 as a minor component.

${ }^{9}$ Conjugated linolenic acid. 
Table 4. Effects of dietary oilseed supplements fed over 2 consecutive lactations (105 \pm 6 wk, mean \pm SD) on milk concentrations of major ${ }^{1}$ fatty acids (FA) of cows during early lactation (yr 3) fed a diet containing no oilseeds from $21 \mathrm{~d}$ prepartum to $49 \mathrm{~d}$ postpartum

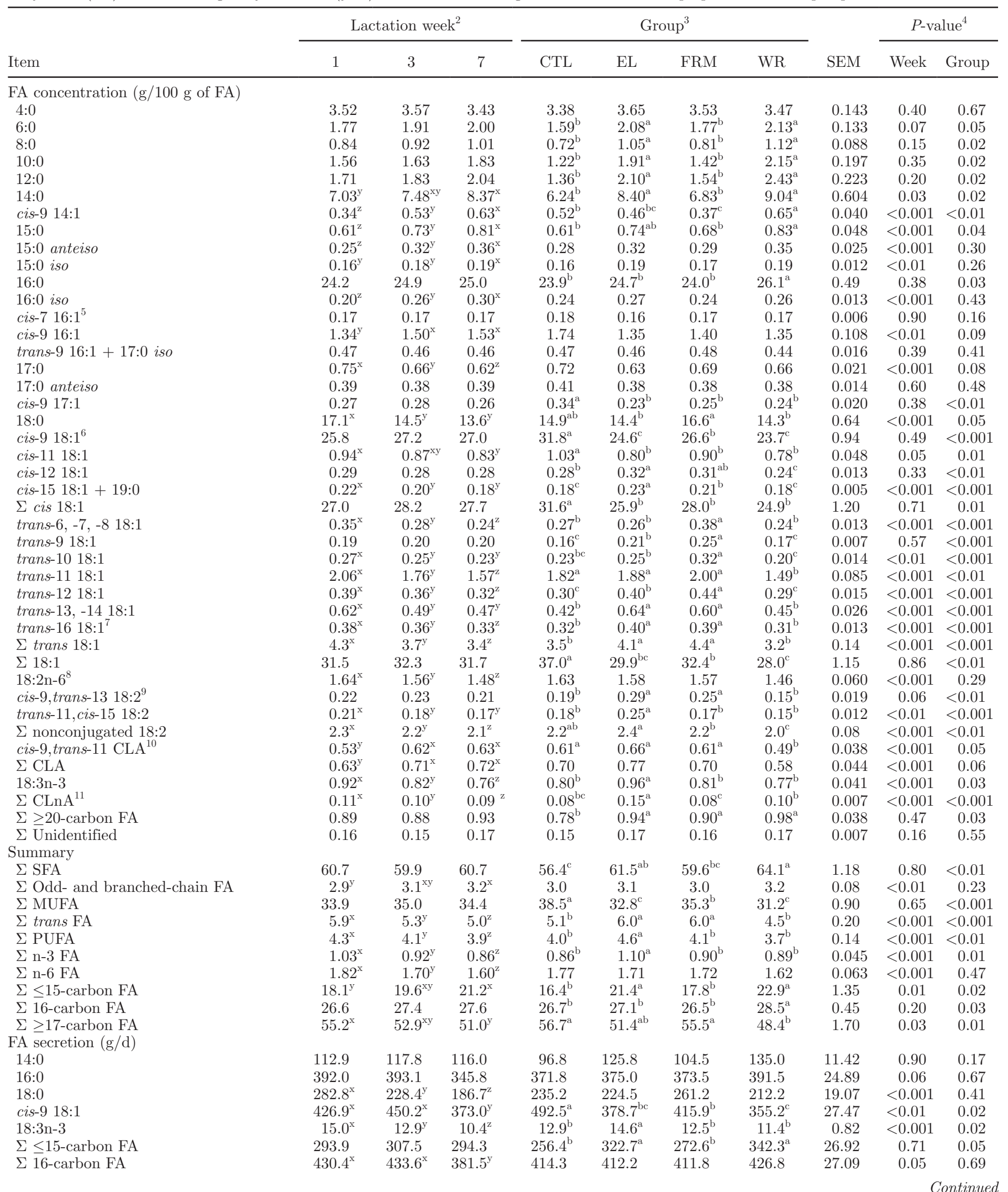


Table 4 (Continued). Effects of dietary oilseed supplements fed over 2 consecutive lactations (105 \pm 6 wk, mean \pm SD) on milk concentrations of major ${ }^{1}$ fatty acids (FA) of cows during early lactation (yr 3) fed a diet containing no oilseeds from $21 \mathrm{~d}$ prepartum to $49 \mathrm{~d}$ postpartum

\begin{tabular}{|c|c|c|c|c|c|c|c|c|c|c|}
\hline \multirow[b]{2}{*}{ Item } & \multicolumn{3}{|c|}{ Lactation week $^{2}$} & \multicolumn{4}{|c|}{ Group $^{3}$} & \multirow[b]{2}{*}{ SEM } & \multicolumn{2}{|c|}{$P$-value ${ }^{4}$} \\
\hline & 1 & 3 & 7 & CTL & $\mathrm{EL}$ & FRM & WR & & Week & Group \\
\hline cis-9 $14: 1 /($ cis-9 $14: 1+14: 0)$ & $0.048^{\mathrm{y}}$ & $0.066^{\mathrm{x}}$ & $0.071^{\mathrm{x}}$ & $0.079^{\mathrm{a}}$ & $0.051^{\mathrm{c}}$ & $0.051^{\mathrm{c}}$ & $0.065^{\mathrm{b}}$ & 0.0040 & $<0.001$ & $<0.001$ \\
\hline cis-9 16:1/(cis-9 16:1 + 16:0) & $0.053^{\mathrm{y}}$ & $0.058^{\mathrm{x}}$ & $0.058^{\mathrm{x}}$ & 0.067 & 0.053 & 0.055 & 0.050 & 0.0043 & 0.04 & 0.07 \\
\hline cis-9 18:1/( cis-9 18:1 + 18:0) & $0.60^{\mathrm{y}}$ & $0.65^{\mathrm{x}}$ & $0.66^{\mathrm{x}}$ & $0.67^{\mathrm{a}}$ & $0.63^{\mathrm{b}}$ & $0.62^{\mathrm{b}}$ & $0.63^{\mathrm{b}}$ & 0.010 & $<0.001$ & 0.03 \\
\hline
\end{tabular}

${ }^{\mathrm{x}-\mathrm{z}}$ Within a row and between lactation week, means with different superscripts differ at $P<0.05$.

${ }^{\mathrm{a}-\mathrm{c}}$ Within a row and between groups, means with different superscripts differ at $P<0.05$.

${ }^{1}$ Major FA: $\geq 0.15 \mathrm{~g} / 100 \mathrm{~g}$ of FA.

${ }^{2}$ Measured at $6.4 \pm 1.0,20.4 \pm 1.1$, and $48.4 \pm 1.1$ DIM (mean \pm SD) for lactation wk 1, 3, and 7, respectively.

${ }^{3}$ All cows $(n=19)$ received a diet based on grass silage and grass hay (forage:concentrate ratio of 70:30, DM basis) containing no oilseed supplement, after having received grass-based diets containing no oilseed supplement (control, CTL, $\mathrm{n}=4$ ) or 2.5 to $5.1 \%$ of oil in diet DM from extruded linseeds (EL, $\mathrm{n}=4$ ), cold-pressed fat-rich rapeseed meal (FRM, $\mathrm{n}=6$ ), or whole unprocessed rapeseeds $($ WR, $\mathrm{n}=5)$ over 2 consecutive lactations.

${ }^{4}$ Interaction of week by group was not significant $(P>0.10)$, except for trans-6, -7, -8 18:1; 18:3n-3; $\Sigma$ CLnA; and $\Sigma$ n-3 FA concentrations and cis-9 18:1 and $\Sigma \geq 17$-carbon FA secretions $(P<0.05)$, and tended to be significant for trans-12 18:1 concentration and 18:0 secretion $(P \leq 0.10)$.

${ }^{5}$ Contains cis- $816: 1$ as a minor component.

${ }^{6}$ Contains cis-10 18:1 and trans-15 18:1 as minor components.

${ }^{7}$ Contains cis-14 18:1 as a minor component.

${ }^{8}$ Contains cis-9,cis-15 18:2 and cis-9 19:1 as minor components.

${ }^{9}$ Contains cis-10,trans-14 18:2 as a minor component.

${ }^{10}$ Contains trans-7, cis-9 CLA and trans-8, cis-10 CLA as minor components.

${ }^{11}$ Conjugated linolenic acid.

lactation wk 1 to 7 , whereas trans-9 12:1 and trans-5 15:1 concentrations increased $(P<0.01)$ during the same period (Table 4, Figure 2F, and Supplemental Table S1; http://dx.doi.org/10.3168/jds.2014-8578). Concentrations of conjugated FA in milk were only slightly affected by lactation week. Abundances of cis9,trans-11 CLA and unresolved trans-9,trans-11 CLA and trans-10,trans-12 CLA increased $(P \leq 0.03)$ from lactation wk 1 to 3 , whereas cis-9,trans-11,cis-15 CLnA concentration decreased $(P<0.001)$ from lactation wk 1 to 7 (Table 4, Figure 2H, and Supplemental Table S1; http://dx.doi.org/10.3168/jds.2014-8578). Milk fat $\Delta^{9}$-desaturase product/(product + substrate) concentration ratios increased $(P \geq 0.04)$ from lactation wk 1 to 3 and remained unchanged by wk 7 (Table 4 ).

Carry-Over Effects of Previous Oilseed Supplementation. Groups WR and EL increased $(P=0.02)$ milk concentrations of total SFA and FA containing $\leq 15$ carbon atoms but decreased $(P=0.01)$ concentrations of total MUFA and $\geq 17$ carbon FA, compared with the CTL and FRM. Relative to the CTL, cows previously fed oilseeds decreased $(P=0.01)$ milk total cis 18:1 and increased $(P=0.03)$ total $\geq 20$-carbon FA, whereas EL and FRM increased $(P<0.001)$ total trans 18:1 FA and total trans FA. Compared with other treatments, EL increased $(P \leq 0.01)$ milk total PUFA, n-3
PUFA, and CLnA concentrations. Furthermore, WR increased $(P=0.01)$ milk total CLnA concentration during lactation wk 1 compared with CTL and FRM (Table 4; $P=0.01$ for lactation week $\times$ group interaction). Relative to the CTL and FRM treatments, EL and WR increased $(P \leq 0.05)$ milk 6 - to 15 -carbon SFA and 10- to 14-carbon cis-9 MUFA but decreased $(P<$ 0.001) cis-9 18:1 concentration (Table 4, Figure 2E, and Supplemental Table S1; http://dx.doi.org/10.3168/ jds.2014-8578). However, treatments had no carry-over effects $(P>0.10)$ on the outputs of 14:0, 16:0, and 18:0 in milk. Concentrations of almost all n-3 PUFA was influenced by previous oilseed supplements. Compared with other groups, milk 18:3n-3 and 20:4n-3 concentrations were higher $(P \leq 0.03)$ for EL, and 20:5n-3, unresolved 22:5n-3 and 26:0, and 22:6n-3 were higher $(P<0.01)$ for EL and WR (Table 4, Figure $2 \mathrm{G}$, and Supplemental Table S1; http://dx.doi.org/10.3168/ jds.2014-8578). Relative to other treatments, the secretion of 18:3n-3 in milk was highest for EL $(P=0.02)$.

Among milk concentrations of $\leq 17$-carbon ruminal biohydrogenation $(\mathbf{R B H})$ intermediates, previous oilseed supplements decreased $(P<0.01)$ milk cis-11 16:1 concentration, whereas WR increased $(P<0.01)$ milk trans-9 12:1 concentration and EL and FRM increased $(P \leq 0.01)$ milk trans-10, $-11,-12$, and $-1416: 1$ 
concentrations. Compared with the CTL, WR did not increase $(P>0.10)$ milk concentrations of 18-carbon RBH intermediates, other than trans-10,trans-14 18:2 and cis-9,trans-11,cis-15 CLnA during lactation wk 1 (Figure $2 \mathrm{H}$ and Supplemental Table S1; http://dx.doi. org/10.3168/jds.2014-8578; $P<0.01)$. However, WR decreased $(P \leq 0.05)$ milk trans-11 18:1 and cis-9,trans-11 CLA concentrations. Conversely, concentrations of most 18-carbon $\mathrm{RBH}$ intermediates were increased by EL or FRM compared with the CTL. Both EL and FRM increased $(P \leq 0.02)$ milk cis-12, -15 , and -16 $18: 1$; trans-9, $-12,-13,-14$, and $-1618: 1 ;$ cis- 9 ,trans-13 18:2; cis-9,trans-14 18:2; trans-9,trans-12 18:2; and trans-11,trans-13 CLA concentrations. Relative to other treatments, EL increased $(P \leq 0.04)$ milk cis-12, cis-15 18:2 and trans-11,cis-15 18:2, unresolved trans-11,cis-13 CLA and 21:0, trans-12,trans-14 CLA, and all CLnA isomer concentrations (Table 4, Figure $2 \mathrm{H}$, and Supplemental Table S1; http://dx.doi.org/10.3168/jds.20148578). In contrast, FRM increased $(P<0.001)$ trans -4 , $-5,-6,-7,-8$, and -10 18:1 concentrations (Table 4, Figure 2F, and Supplemental Table S1; http://dx.doi. org/10.3168/jds.2014-8578) compared with other treatments. Both the $\Delta^{9}$-desaturation ratios for $14: 0$ and 18:0 were higher $(P \leq 0.03)$ for the CTL, whereas the $\Delta^{9}$-desaturation ratio for trans-11 18:1 was lower $(P<$ 0.01 ) for FRM (Table 4) compared with other treatments.

\section{DISCUSSION}

\section{Effects of Oilseed Supplements on Adipose Tissue FA Composition}

Oilseed treatments had limited influence on subcutaneous AT FA composition, other than EL increasing 18:3n-3, trans-16 18:1, trans-11, cis-15 18:2, and $\Delta 9,11,15$ CLnA concentrations, and FRM increased trans-6, -7, -8, -9, -10, and -11 18:1. Such changes in the distribution of trans FA isomers in AT to oilseed supplements correspond to the differences in milk FA composition over the 2-yr study period (Lerch et al., $2012 b, c)$, although the increases in trans FA concentrations to EL and FRM relative to the CTL were 2- to 3 -fold lower in AT than for milk fat.

Oilseed supplements had no effect on 12:0, 14:0, or 16:0 concentrations in AT, which is in marked contrast with the decrease in medium-chain SFA concentrations in milk (Lerch et al., 2012b). Adipose-tissue concentration of long-chain (carbon chain $\geq 20$ ) n-3 FA remained low and was unaffected by long-term EL supplementation. The lack of enrichment could be explained, at least in part, by the analysis of only the neutral lipid fraction FA, whereas long-chain PUFA are mainly in- corporated into polar lipids (Scollan et al., 2001), and by the limited elongation of 18:3n-3 in AT (Shingfield et al., 2013).

Shorter periods ( 5 to $7 \mathrm{wk}$ ) of dietary supplementation prepartum with crushed sunflower seeds or linseeds supplying 3.5 to $4 \%$ of oil in DMI had very small or no effect on subcutaneous AT FA composition in dairy cows, with only marginal increases in $18: 2 \mathrm{n}-6$ or $18: 3 \mathrm{n}-$ 3 concentrations due to sunflower seed (Morel et al., 2008) or linseed (Leiber et al., 2011), respectively $(+0.1$ $\mathrm{g} / 100 \mathrm{~g}$ of total FA in each case). However, in growing cattle, long-term (17 to $40 \mathrm{wk}$ ) feeding of crushed linseeds providing 3 to $4 \%$ of oil in DMI increased subcutaneous AT 18:3n-3 concentration in total lipids (i.e., neutral plus polar) between +0.3 and $+0.5 \mathrm{~g} / 100 \mathrm{~g}$ of total FA (Casutt et al., 2000; Scollan et al., 2001; Nassu et al., 2011). Changes in 18:3n-3 were also accompanied by increases in the concentration of intermediates formed during ruminal 18:3n-3 biohydrogenation $(+0.1$ to $1.2 \mathrm{~g} / 100 \mathrm{~g}$ of total FA for cis-16 18:1, trans-16 18:1, cis-9,trans-13 18:2, trans-11,cis-15 18:2, and $\Delta 9,11,15$ CLnA; Nassu et al., 2011). Consistent with these findings, the EL treatment resulted in higher concentrations $(+0.1$ to $0.2 \mathrm{~g} / 100 \mathrm{~g}$ of total FA) of 18:3n-3, cis-16 18:1, trans-16 18:1, and $\Delta 9,11,15$ CLnA. However, enrichment of cis-9,trans-13 18:2 and trans-11,cis-15 18:2 of +0.3 and $+0.1 \mathrm{~g} / 100 \mathrm{~g}$ of total FA, relative to the CTL, respectively, were lower than previous reports.

Discrepancies among studies in late-gestation dairy cows (Morel et al., 2008; Leiber et al., 2011) and the present study could be explained by both differences in the duration of oilseed supplementation and physiological state. In this study, dairy cows experienced periods of AT mobilization and accretion, whereas changes in BW and BCS of dairy cows were much smaller in previous short-term experiments (Morel et al., 2008; Leiber et al., 2011), as would be expected for cows during late pregnancy with an energy balance slightly positive or close to zero. The transfer rate of FA from the diet into AT is heavily dependent on energy balance in lactating cows. Estimated transfer of 18:2 during infusion of rapeseed oil at the duodenum into AT was substantial (14\%) during a period of positive energy balance in mid-lactation, when AT lipoprotein lipase activity was high, compared with negligible transfer in cows experiencing negative energy balance in early lactation, when AT lipoprotein lipase activity was very low (Chilliard et al., 1991).

\section{Milk FA Composition}

Effects of Lactation Week. As lactation progressed, the concentration of FA synthesized de novo increased, whereas the concentration of preformed FA decreased. 
This time pattern is in agreement with reports in the literature (Chilliard et al., 1991; Leiber et al., 2011; Pires et al., 2013) and could be related to limiting availability of precursors for de novo FA synthesis, and extensive mobilization of preformed FA from body-fat reserves during early lactation (Chilliard et al., 2000). Among preformed milk FA, concentrations of cis-9 unsaturated FA did not change as lactation progressed, whereas the concentration of the corresponding $\Delta^{9}$ desaturase precursors declined. This pattern of changes in milk fat composition indicated a lower $\Delta^{9}$-desaturase ratio during lactation wk 1 compared with wk 3 and 7. Such effect could be explained by a substantial $\Delta^{9}$-desaturase mRNA abundance in mammary gland during lactation, with an increase until 60 DIM (Bionaz and Loor, 2008). Differences among the kinetics of $\Delta^{9}$-desaturase product and substrate concentrations in milk fat during early lactation have been observed previously for cis-9 18:1/18:0 and cis-9,trans-11 CLA/ trans-11 18:1 (Santschi et al., 2009; Leiber et al., 2011; Pires et al., 2013). However, in earlier studies, the milk concentration of total 18:1 FA decreased continuously $(-6.0 \mathrm{~g} / 100 \mathrm{~g}$ of total FA from lactation wk 1 to 6 ; Decaen and Journet, 1967; Decaen and Adda, 1970; and $-12.0 \mathrm{~g} / 100 \mathrm{~g}$ of total FA from lactation wk 1 to 9; Chilliard et al., 1991), and cis-9 18:1 concentration decreased from lactation wk 1 to $6(-5.9 \mathrm{~g} / 100 \mathrm{~g}$ of total FA; Gross et al., 2011).

Carry-Over Effects of Oilseed Supplements. The current study provides clear evidence of carryover effects of long-term EL or FRM supplementation on the distribution of long-chain unsaturated FA isomers in milk fat. Carry-over effects persisted into wk 7 of lactation, i.e., $10 \mathrm{wk}$ after the withdrawal of oilseed supplements. Specifically, EL (rich in 18:3n3 ) increased the milk concentration and secretion of 18:3n-3 and intermediates formed during 18:3n-3 RBH (Shingfield et al., 2010). In contrast, FRM (rich in cis-9 18:1) increased the abundance and yield of intermediates formed during RBH of cis-9 18:1 (Shingfield et al., 2010) and cis-9,trans-13 18:2 derived from trans-13 18:1 desaturation (Glasser et al., 2008). This study was limited to the 7 first weeks of lactation because carryover effects were expected to be observed principally during early lactation, when cows experience extensive body-fat mobilization.

Carry-over effects of EL and FRM supplementation on the milk profile of 18-carbon unsaturated isomers were consistent with the effects of these treatments on the FA composition of neutral lipid in AT fraction. Even though the FA composition of AT and milk fat profile were not measured simultaneously (yr 2 for AT and yr 3 for milk fat), high correlations were observed among the concentrations of trans-6, -7 , and -8 18:1; trans-9 18:1; trans-10 18:1; trans-16 18:1; unresolved cis-16 18:1 and cis-9,trans-14 18:2; trans-11,cis-15 18:2; and cis-9,trans-11,cis-15 CLnA in AT (lactation wk 1, yr 2) and milk fat (lactation wk 1 , yr 3$)(\mathrm{r}=+0.82$, $+0.62,+0.67,+0.67,+0.75,+0.74$, and +0.93 , respectively; $P<0.01 ; \mathrm{n}=17)$. However, the strength of these relationships was weaker between AT (lactation wk 1, yr 2) and milk from lactation wk 3 and 7 (yr 3) but remained significant for trans- $6,-7,-8$, and -16 18:1 and cis-9,trans-11, cis- 15 CLnA $(\mathrm{r}=+0.62,+0.70$ and +0.86 , respectively, for lactation wk 3 and $\mathrm{r}=$ $+0.66,+0.62$, and +0.77 , respectively, for lactation wk $7 ; P<0.01 ; \mathrm{n}=17)$. In contrast, changes in 20 - and 22-carbon n-3 FA concentrations in milk and AT differed. Milk concentration (yr 3) of 18:3n-3 elongation products (i.e., 20:4n-3, 20:5n-3, unresolved 22:5n-3 and 26:0, and 22:6n-3) were marginally higher $(P \leq 0.01)$ for cows receiving EL prepartum compared with other treatments, whereas only small and numerical increases were observed in AT (yr 2) for 20:4n-3, 20:5n-3, and 22:5n-3 $(P>0.10)$.

Present results differ from early studies reporting that extruded or crushed linseeds (supplying 2.5 or $3.3 \% \mathrm{DM}$ of oil) increased 18:3n-3, trans-16 18:1, and trans-11,cis-15 18:2 concentrations in colostrum (at 1 and 2 DIM), but effects were not detected after 7 DIM (Santschi et al., 2009; Leiber et al., 2011). Carry-over effects of prepartum oilseed supplementation on colostrum FA composition (Santschi et al., 2009; Leiber et al., 2011) could be attributed to the presence of oilseeds in the digestive tract of the cows, because oilseed supplements were withdrawn from the diet at calving. Differences among studies may also reflect variations in the duration of oilseed supplementation and energy balance of animals. In previous studies (Santschi et al., 2009; Leiber et al., 2011), cows received oilseeds for 5 to $7 \mathrm{wk}$ prepartum when BCS did not increase $(-0.2$ to +0.1 points, $P>0.10)$, whereas during the 105-wk supplementation period in the present study, cows experienced an increment of 1.9 BCS points during a 36-wk interval (mean of EL and FRM groups; from turn-out to pasture in yr 2 until calving in yr 3 of experiment).

Cows from the CTL and FRM groups had a lower concentration and secretion of milk FA synthesized de novo and higher concentration and secretion of preformed milk FA compared with EL and WR groups. Such effects are probably due to the higher mobilization of body-fat reserves for the CTL and FRM, as indicated by the higher plasma NEFA concentration for these treatments compared with EL and WR. Overall, total $\leq 15$ - and $\geq 17$-carbon FA concentrations were inversely correlated with estimated energy balance (r $=+0.62$ and -0.62 , respectively; $P<0.001 ; \mathrm{n}=19)$ 
and with plasma NEFA concentration $(\mathrm{r}=-0.69$ and +0.65 , respectively; $P<0.001 ; \mathrm{n}=19$ ). These findings are in agreement with previous studies examining the influence of body-fat mobilization on milk FA composition in cows during early lactation (Decaen and Journet, 1967; Pires et al., 2013).

\section{Carry-Over Effects of Oilseed Supplements on Dairy Cow Performance}

Results of the present experiment do need to be interpreted with caution because of the relatively modest number of cows in each treatment group. During lactation wk 1, milk fat content and yield tended to be lower for EL and WR compared with the CTL and FRM, effects most likely explained by differences in body-fat mobilization as would be implicated by plasma NEFA concentrations. Milk protein content and yield were higher during yr 3 for cows that had received EL prepartum compared with the CTL. This could be linked to the lower plasma NEFA concentration and higher energy balance for EL than CTL, which suggest a nutritional status less limiting for milk protein synthesis in EL group during yr 3, as milk protein content is primarily influenced by energy balance (Coulon and Remond, 1991). Multiple mechanisms explaining the relationship between energy balance and milk protein content have been proposed. For instance, increased availability of propionate and microbial protein would influence the nutritional physiology of the lactating dairy cow and enhance milk protein secretion (Jenkins and McGuire, 2006). Conversely, during indoor periods and oilseed supplementation of preceding study yr 1 and 2, EL decreased milk protein content compared with the CTL, with no effects on plasma NEFA concentration or energy balance (Lerch et al., 2012a). Plasma BHBA concentration increased postpartum in all cows and exceeded $1,200 \mu M$ during lactation wk 3, indicative of subclinical ketosis (Roberts et al., 2012). Pires et al. (2013) recorded similar plasma BHBA concentrations at 3 wk postpartum, in cows housed on the same experimental farm in the same year, and offered a similar grass silage-based diet. In both cases, no signs of clinical ketosis were detected.

In summary, long-term ( $2 \mathrm{yr}$ ) dietary oilseed supplementation altered the FA composition of neutral lipids in subcutaneous AT and, despite being withdrawn from the diet $21 \mathrm{~d}$ before calving, influenced milk FA composition early postpartum in the subsequent lactation. Compared with the CTL, EL increased the concentrations of 18:3n-3 and intermediates of ruminal 18:3n-3 biohydrogenation in AT, whereas FRM increased the abundance of ruminal cis-9 18:1 intermediates. Similar changes in these specific FA to EL and FRM were detected in milk fat during the first 7 wk of the subsequent lactation. Carry-over effects of long-term oilseed supplementation on milk FA persisted for at least 7 wk in lactation, which corresponded to $10 \mathrm{wk}$ after the withdrawal of oilseeds from the diet.

\section{CONCLUSIONS}

Results support the hypothesis that long-term feeding of oilseed supplements alters AT FA composition and influences milk FA composition during early postpartum of the subsequent lactation when oilseed supplements were removed from the diets for more than 3 wk. Nevertheless, the carry-over effects on milk FA composition following the withdrawal of oilseeds in the diet during early lactation, with increases in trans FA, n-3 FA, and CLnA, were relatively modest compared with the responses to long-term oilseed supplementation (Lerch et al., 2012b,c).

\section{ACKNOWLEDGMENTS}

The authors thank M. Barbet and the team of the Monts d'Auvergne experimental unit of Orcival (INRA, UE1296, Orcival, France) for the feeding, milking, milk and blood sampling, and diligent management of experimental cows; D. Bany and E. Tixier (INRA, UMRH1213, Saint-Genès-Champanelle, France) for technical support during the analysis of feeds and FA composition of adipose tissue; M. Tourret (INRA, UMRH1213) for plasma metabolite analyses; and M. Bonnet (INRA, UMRH1213) for helpful discussions during preparation of the experimental protocol and collection of biopsies. This research was supported, in part, by the European TRUEFOOD program (Traditional United Europe Food), an integrated project funded by the European Commission under the 6th Framework Program for RTD (Contract No. FOODCT-2006-016264). S. Lerch acknowledges financial support of a PhD studentship provided by In Vivo NSA (Paris, France), Organisation Nationale Interprofessionnelle des Graines et Fruits Oléagineux (ONIDOL, Paris, France), and Association Nationale de la Recherche Technique (ANRT, Paris, France), along with a Convention Industrielle de Formation à la Recherche en Entreprise (CIFRE) fellowship.

\section{REFERENCES}

Bionaz, M., and J. J. Loor. 2008. Gene networks driving bovine milk fat synthesis during the lactation cycle. BMC Genomics 9:366386.

Casutt, M. M., M. R. L. Scheeder, D. A. Ossowski, F. Sutter, B. J. Sliwinski, A. A. Danilo, and M. Kreuzer. 2000. Comparative evaluation of rumen-protected fat, coconut oil and various oilseeds 
supplemented to fattening bulls - 2 . Effects on composition and oxidative stability of adipose tissues. Arch. Tierernahr. 53:25-44.

Chilliard, Y., A. Ferlay, R. M. Mansbridge, and M. Doreau. 2000. Ruminant milk fat plasticity: Nutritional control of saturated, polyunsaturated, trans and conjugated fatty acids. Ann. Zootech. 49:181-205.

Chilliard, Y., G. Gagliostro, J. Flechet, J. Lefaivre, and I. Sebastian. 1991. Duodenal rapeseed oil infusion in early and midlactation cows. 5. Milk fatty acids and adipose tissue lipogenic activities. J. Dairy Sci. 74:1844-1854.

Chilliard, Y., F. Glasser, A. Ferlay, L. Bernard, J. Rouel, and M. Doreau. 2007. Diet, rumen biohydrogenation and nutritional quality of cow and goat milk fat. Eur. J. Lipid Sci. Technol. 109:828855.

Coulon, J. B., and B. Remond. 1991. Effects of variations in the energy supply on milk yield and milk composition in the dairy cow. Prod. Anim. 4:49-56.

Decaen, C., and J. Adda. 1970. Changes in secretion of fatty acids of milk fat during lactation in cows. Ann. Biol. Anim. Biochim. Biophys. 10:659-677.

Decaen, C., and M. Journet. 1967. Changes in secretion of main fatty acids in milk and the concentration of free fatty acids in blood of cows at the start of lactation. Ann. Biol. Anim. Biochim. Biophys. $7: 131-143$.

Ferlay, A., M. Doreau, C. Martin, and Y. Chilliard. 2013. Effects of incremental amounts of extruded linseed on the milk fatty acid composition of dairy cows receiving hay or corn silage. J. Dairy Sci. 96:6577-6595

Folch, J., M. Lees, and G. H. Sloane Stanley. 1957. A simple method for the isolation and purification of total lipides from animal tissues. J. Biol. Chem. 226:497-509.

Givens, D. I. 2010. Milk and meat in our diet: Good or bad for health? Animal 4:1941-1952.

Glass, R. L. 1971. Alcoholysis, saponification and the preparation of fatty acid methyl esters. Lipids 6:919-925.

Glasser, F., M. Doreau, A. Ferlay, and Y. Chilliard. 2007. Technical note: Estimation of milk fatty acid yield from milk fat data. J. Dairy Sci. 90:2302-2304.

Glasser, F., A. Ferlay, M. Doreau, P. Schmidely, D. Sauvant, and Y. Chilliard. 2008. Long-chain fatty acid metabolism in dairy cows: A meta-analysis of milk fatty acid yield in relation to duodenal flows and de novo synthesis. J. Dairy Sci. 91:2771-2785.

Gross, J., H. A. Van Dorland, R. M. Bruckmaier, and F. J. Schwarz 2011. Milk fatty acid profile related to energy balance in dairy cows. J. Dairy Res. 78:479-488.

INRA. 2006. PrevAlim-Version professionnelle intégrale. 3.23 ed. Educagri Éditions, Theix, France.

INRA. 2007. Alimentation des bovins, ovins et caprins. Besoins des Animaux-Valeur des aliments. Table INRA 2007. INRA, Versailles, France.

Jenkins, T. C., and M. A. McGuire. 2006. Major advances in nutrition: Impact on milk composition. J. Dairy Sci. 89:1302-1310.

Juaneda, P., and G. Rocquelin. 1985. Rapid and convenient separation of phospholipids and non phosphorus lipids from rat heart using silica cartridges. Lipids 20:40-41.

Leiber, F., R. Hochstrasser, H. R. Wettstein, and M. Kreuzer. 2011. Feeding transition cows with oilseeds: Effects on fatty acid composition of adipose tissue, colostrum and milk. Livest. Sci. 138:1-12.

Lerch, S., A. Ferlay, D. Pomiès, B. Martin, J. A. A. Pires, and Y. Chilliard. 2012a. Rapeseed or linseed supplements in grass-based diets: Effects on dairy performance of Holstein cows over 2 consecutive lactations. J. Dairy Sci. 95:1956-1970.
Lerch, S., A. Ferlay, K. J. Shingfield, B. Martin, D. Pomiès, and Y Chilliard. 2012b. Rapeseed or linseed supplements in grass-based diets: Effects on milk fatty acid composition of Holstein cows over two consecutive lactations. J. Dairy Sci. 95:5221-5241.

Lerch, S., K. J. Shingfield, A. Ferlay, A. Vanhatalo, and Y. Chilliard. 2012c. Rapeseed or linseed in grass-based diets: Effects on conjugated linoleic and conjugated linolenic acid isomers in milk fat from Holstein cows over 2 consecutive lactations. J. Dairy Sci 95:7269-7287.

Loor, J. J., K. Ueda, A. Ferlay, Y. Chilliard, and M. Doreau. 2004. Biohydrogenation, duodenal flow, and intestinal digestibility of trans fatty acids and conjugated linoleic acids in response to dietary forage: Concentrate ratio and linseed oil in dairy cows. J. Dairy Sci. 87:2472-2485.

Morel, I., M. Collomb, S. Richter, M. Reist, and R. M. Bruckmaier. 2008. Influence of feeding strategy during the dry period on the composition of milk at the beginning of lactation. Rev. Suisse Agric. 40:229-234.

Nassu, R. T., M. E. R. Dugan, M. L. He, T. A. McAllister, J. L. Aalhus, N. Aldai, and J. K. G. Kramer. 2011. The effects of feeding flaxseed to beef cows given forage based diets on fatty acids of longissimus thoracis muscle and backfat. Meat Sci. 89:469-477.

Palmquist, D. L., A. D. Beaulieu, and D. M. Barbano. 1993. Feed and animal factors influencing milk fat composition. J. Dairy Sci. 76:1753-1771.

Pires, J. A. A., C. Delavaud, Y. Faulconnier, D. Pomiès, and Y. Chilliard. 2013. Effects of body condition score at calving on indicators of fat and protein mobilization of periparturient Holstein-Friesian cows. J. Dairy Sci. 96:6423-6439.

Roberts, T., N. Chapinal, S. J. LeBlanc, D. F. Kelton, J. Dubuc, and T. F. Duffield. 2012. Metabolic parameters in transition cows as indicators for early-lactation culling risk. J. Dairy Sci. 95:30573063.

Santschi, D. E., H. R. Wettstein, F. Leiber, A. K. M. Witschi, and M. Kreuzer. 2009. Colostrum and milk fatty acids of dairy cows as influenced by extruded linseed supplementation during the transition period. Can. J. Anim. Sci. 89:383-392.

SAS Institute Inc. 2003. SAS/STAT User's Guide. SAS Institute Inc., Cary, NC.

Scollan, N. D., N. J. Choi, E. Kurt, A. V. Fisher, M. Enser, and J. D. Wood. 2001. Manipulating the fatty acid composition of muscle and adipose tissue in beef cattle. Br. J. Nutr. 85:115-124.

Shingfield, K. J., S. Ahvenjarvi, V. Toivonen, A. Arola, K. V. V. Nurmela, P. Huhtanen, and J. M. Griinari. 2003. Effect of dietary fish oil on biohydrogenation of fatty acids and milk fatty acid content in cows. Anim. Sci. 77:165-179.

Shingfield, K. J., L. Bernard, C. Leroux, and Y. Chilliard. 2010. Role of trans fatty acids in the nutritional regulation of mammary lipogenesis in ruminants. Animal 4:1140-1166.

Shingfield, K. J., M. Bonnet, and N. D. Scollan. 2013. Recent developments in altering the fatty acid composition of ruminant-derived foods. Animal 7:132-162.

Shingfield, K. J., Y. Chilliard, V. Toivonen, P. Kairenius, and D. I. Givens. 2008. Trans fatty acids and bioactive lipids in ruminant milk. Pages 3-65 in Bioactive Components of Milk. Vol. 606. Springer-Verlag Berlin, Berlin, Germany.

Sukhija, P. S., and D. L. Palmquist. 1988. Rapid method for determination of total fatty acid content and composition of feedstuffs and feces. J. Agric. Food Chem. 36:1202-1206. 